
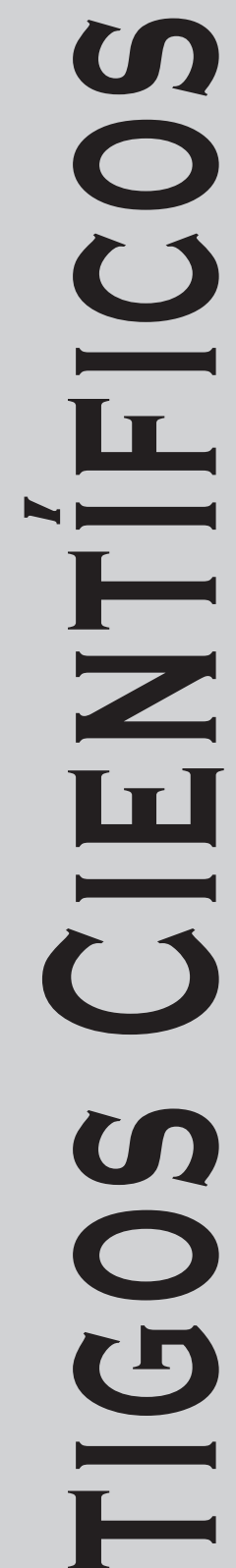
ac

Revista Música Hodie, Goiânia - V.14, 238p., n.1, 2014 
Isso foi demonstrado nos concertos em que apresentei a obra, em Madri e em Brasília, e nos debates que se seguiram com o público.

Os indícios de uma possível eloquência na música eletroacústica, que demonstra a intenção do compositor em seduzir a escuta por meio de gestos poéticos, acende luzes que podem iluminar as estruturas da nova música como algo mais do que uma simples meta-linguagem.

\section{Referências}

ANTUNES, Jorge (1998). Volatas e Cascatas: primeiras identificações de semantemas musicais na música eletroacústica, com base em significações do tipo "emoção forte". In: Anais do XI Encontro Nacional da Anppom. XI Encontro Nacional da Anppom, Campinas, 1998, 156-161.

. (1999). Baques e Quicadas: novas identificações de semantemas musicais na música eletroacústica, com base em significações do tipo "emoção forte". In: Anais do XII Encontro Nacional da Anppom. XII Encontro Nacional da Anppom, Salvador, 1999, CD-Rom.

. (2001a). O Semantema. In: Opus no 7. In: Revista eletrônica da Anppom, 2001. Disponível em: <http://www.musica.ufmg.br/anppom/opus/opus7/antmain.htm>. Acessado em: 28/05/2006.

. (2001b). Clamores e Argumentos: identificação de semantemas musicais na música eletroacústica, com base em significações do tipo "persuasão". In: Anais do XI Encontro Nacional da Anppom. XI Encontro Nacional da ANPPOM, Belo Horizonte, 2001, 253-260.

. (2004). Anáfora, Epístrofe e Poliptóton: identificação de figuras de linguagem na música eletroacústica, no âmbito da retórica e da eloquência, com base em significações do tipo "persuasão" In: Anais do XIV Encontro Nacional da Anppom. XIV Encontro Nacional da Anppom, Porto Alegre, 2004.

ARISTÓTELES (1997). Poética. São Paulo: Editora Cultrix. Tradução direta do grego e do latim de Jaime Bruna: A Poética Clássica.

COOPER, Lane (1967). Aristotle on the Art of Poetry, an amplified version with supplementary illustrations. Ithaca: Cornell University Press.

GARDES-TAMINE, J. (1996). La réthorique. Paris: Armand Colin.

GODOY, Esther (1978). Questions and Politeness, Cambridge: Cambridge Press.

QUINTILIANO, M. Fábio (1944). Instituições Oratórias. São Paulo: Edições Cultura, 1944. Tradução de Jerônimo Soares Barbosa. 2 Tomos.

\footnotetext{
Jorge Antunes - Formou-se em violino, composição e regência. Realizou estudos pós-graduados em composição no Instituto Torcuato Di Tella de Buenos Aires. Estudou no Instituto de Sonologia da Universidade de Utrecht, com uma bolsa do governo holandês, e no Groupe de Recherches Musicales de l'ORTF, onde atuou como compositor-estagiário sob a orientação de Pierre Schaeffer. Fez o Doutorado em Estética Musical na Sorbonne, Universidade de Paris VIII, tendo Daniel Charles como orientador. Ingressou em 1973 no corpo docente da Universidade de Brasília. Foi Professor Titular de Composição Musical na UnB até 2011, quando se aposentou. Continua vinculado àquela Universidade, como Pesquisador Sênior. Obteve vários prêmios nacionais e internacionais. Tem vários CDs, DVDs e livros publica- dos. É membro da Academia Brasileira de Música e Presidente da Sociedade Brasileira de Música Eletroacústica. Suas obras são publicadas por importantes editoras internacionais: Salabert, Breitpkof\&Hartell, Gerig, Ricordi, Sistrum, Billaudot e Suvini Zerboni.
} 


\title{
A Inversão das Distâncias - do Som do Corpo ao Corpo do Som ${ }^{1}$
}

Flo Menezes (IA/Universidade Estadual Paulista, São Paulo, SP) flo@flomenezes.mus.br

\begin{abstract}
Resumo: Este ensaio discorre sobre a relação entre o corpo do compositor e seus sons, abordando, por um viés filosófico, o processo de objetivação do som no decurso da história da escritura musical, até desaguar no advento das poéticas eletroacústicas. Lá chegando, o texto discorre sobre a dialética entre recursos analógicos e digitais e sobre os problemas mais pungentes da composição eletroacústica nos dias de hoje.

Palavras-chave: Composição musical; Poética eletroacústica; Filosofia da música.
\end{abstract}

The Inversion of the Distances - From the Sound of the Body to the Body of Sound

Abstract: This essay deals with the relationship between the body of the composer and his sounds, approaching - by a philosophical point of view - the process of objectivation of sound along the history of musical writing (escritura $=$ musical scripture), until coming up the emergence of electroacoustic music. At this point, the text handles with the dialectic between analogical and digital resources and with the most crucial problems of electroacoustic music in our days.

Keywords: Musical composition; Electroacoustic poetics; Philosophy of music.

\section{A expulsão do som}

Em um de meus mergulhos acerca da música feita em tempos ancestrais, deparei-me com uma passagem sobre Josquin Desprez que, em sua aparente obviedade e simplicidade, quase motivo algum teria para que me tivesse chamado tanta atenção. $\mathrm{O}$ trecho reportava-se à maneira pela qual, tão distinta da nossa, a música era então composta, em uma época em que a escritura vocal polifônica se dava pela escrição (o neologismo é meu, para o velho significado, já perdido, do instigante vocábulo latim scriptio, donde decorre toda scriptura = escritura) em partes individuais, separadas umas das outras, ao invés de se fazer uso das "grades" gerais (scores) que, já tendo existido em tempos ainda mais remotos, viria a se tornar prática corrente somente a partir de cerca de 1600:

“Meu professor Josquin [...] jamais deu uma aula sobre música e sequer escreveu
qualquer trabalho teórico, [...] mas ensinou a seus alunos as regras em poucas pa-
lavras, através de aplicações práticas no decurso do canto'. [...] Com tais palavras o
teórico e compositor alemão Adrianus Petit Coclico explicou como Josquin ensinava
música: primeiramente cantando, depois pelo contraponto e, finalmente, pela com-
posição".' (Owens, Jessie Ann. Composers at work: The craft of musical composition
1450-1600. New York: Oxford University Press, 1997, p. 11-12)

Mais que o exercício de um tipo de memória, ao que tudo indica, muito distinta da nossa, em que o compositor, ao escrever separadamente cada parte vocal do tecido polifônico, tinha em mente o que ocorria com as demais vozes já escritas ou ainda por se escrever, sem que tivesse o cômodo controle visual da simultaneidade que a grade da partitura viria a lhe oferecer a partir de Monteverdi e outros, interessou-me sobremaneira, nesse contexto, aquele indissociável liame entre a prática vocal e a própria escritura, que quase brotava, por assim dizer, das próprias cordas vocais do compositor.

A aparente obviedade deste fato histórico emerge como algo peculiar se compararmos as condições daquela prática musical com as que hoje nos deparamos. Em uma realidade diametralmente oposta à nossa, os grandes mestres compositores do passado - da Idade 
Média à Renascença - foram renomados cantores, não raramente dotados de vozes especiais e por tal razão conhecidos e admirados por seus contemporâneos: Johannes Ockeghem com sua famosa voz de baixo; Josquin Desprez, grande mestre cantor; Heinrich Isaac: Jacob Obrecht; Orlando di Lasso... Música e verbalidade eram irmãs gêmeas, e a prática musical advinha do âmago do próprio corpo: dele emanavam as vibrações do aparelho fonador, órgão emissor fundamental do gesto compositivo primordial.

Nesse contexto, a vocalidade tinha de tudo, menos de "instrumentalidade". O som, emanando do próprio corpo do criador, não era produto de um “instrumento”, mas antes de sua alma, e o compositor, ao mesmo tempo receptor e emissor de seus próprios sons.

Com a paulatina metamorfose da escrição em escritura, em que a escrita ou notação musical passa a ser, ela mesma, "instrumento" ou veículo do pensamento processual, o tempo diferido da composição, distinto do tempo real da prática musical, ganha cada vez mais espaço nas elaborações compositivas e assistimos, no decurso dos tempos, a uma cada vez maior instrumentalização dos processos composicionais: quer seja pelos recursos mesmo das escrituras (ou seja, dos processos de elaboração dos materiais na composição, mediadas pela escrita ou notação enquanto seu suporte visual e operacional), quer seja pela especulação/apropriação de outros corpos emissores de sons.

Assim é que o período Barroco, dando vazão à autonomia antes apenas esboçada do gênero puramente instrumental, faz emergir o compositor-instrumentista, cuja voz às vezes silencia para que seus dedos façam emergir os sons de - aí sim sem qualquer titubeio - certos instrumentos. Pensamos logo em Bach, e não sem razão. Mas teria o som vocal silenciado? Às vezes. Mas raras vezes. Ele continua presente, mas co-divide o espaço da prática musical e sobretudo composicional com uma escritura voltada puramente ao universo instrumental. A atuação cada vez mais autônoma dos instrumentos faz com que a própria vocalidade adquira o estatuto de "instrumento" e aquela "naturalidade primária”, primordial, da emissão vocal verte-se em técnicas cada vez mais rebuscadas de impostação do canto. Não à toa assistimos então, nos primórdios do Barroco, à emergência da ópera, em que o canto cindir-se-á em canto de ária, de arioso ou de recitativo, em sofisticada trifurcação da entonação cantábile.

Deflagra-se então o que poderíamos designar por certa “externação corpórea” dos sons: tendo seu ápice no período romântico com os grandes virtuoses - Liszt, Chopin, Paganini... -, o compositor faz com que os sons relativamente se distanciem de seu corpo, manipulando-os por intermédio de outros corpos emissores. A caixa de ressonância de seu tórax é transplantada para a caixa de ressonância do piano, do violino com sua alma. Quando não o manipula diretamente, enquanto compositor-instrumentista, seu pensamento, instrumentalizado, leva a cabo, pelo viés da escritura dirigida a outros instrumentos, a expulsão do som de seu corpo: a respiração que expirava dos pulmões e vazava pela boca através do aparelho fonador encontra eco nos tubos extensivos dos trombones e dos trompetes, prolongando o sopro humano; o batimento de seu coração e a periodicidade de seus passos repercutem no toque dos tambores...

O instrumento como que convida o compositor-cantor de outrora a calar-se. A matéria externa vem ao encontro do compositor para dele arrancar seus sons. Oferece a ele a vibração de seus sons para nele fazer silenciar suas cordas vocais. Encontra-o para extirpar os sons de seu corpo e destituí-los de seu até então irrevogável caráter corpóreo. E, assim fazendo, instiga-o simplesmente, por vezes, a ouvir os sons que compõe sem que, necessariamente, faça parte da prática mesma de sua música. Se antes o compositor atuava como intérprete e emissor de seus sons, ele, agora podendo apenas interpretá-los pela emissão sonora do instrumento que toca e domina, também é convidado, passivamente, a ouvir sua música como qualquer outro. Sua música, descorporalizada de si, pode ser então por outros 
interpretada. O compositor passa a ser o ouvinte passivo - se é que exista tal passividade nos atos intencionais da escuta - de sua música.

\section{Oculus non vidit, nec auris audivit ${ }^{3}$}

Um provável impulso à expurgação corpórea sofrida pelo som em relação a nosso corpo é o fato de que, mesmo sendo o som vibração e, como tal, invisível, expelindo-o para fora de nossa boca e fazendo-o emergir de instrumentos por nós (potencialmente) manipulados, conseguimos ao menos vislumbrar sua proveniência física. Por certo que na prática vocal da antiguidade o compositor-cantor via-se acompanhado de outros corpos-cantores e tal sensação já lhe era conhecida na observação do outro em meio à prática musical. Mas vislumbrar o som proveniente de corpos inanimados, desiguais em comparação ao corpo humano, certamente apresentava-se como situação propícia a esta ilusão de que se nutriu o compositor desde sempre: a de que, vendo a proveniência do som, poderia, ao dele se distanciar, aproximar-se de sua objetivação.

Consciente ou inconscientemente, porém, a história da composição, vasculhando o caminho do som do corpo ao corpo do som, nada mais fez que revisitar o sábio e antigo lema de Anaxágoras, o mesmo que tantas vezes citei em alguns de meus livros como sendo precursor da fenomenologia contemporânea em cerca de dois séculos e meio, em drible sagaz da obviedade. Pois que cada visão não vislumbra aspectos daquilo que os olhos alcançam, mas antes do que jamais qualquer olhar alcançará: "Aquilo que se vê não é mais que um aspecto do invisível"4.

Almejando vislumbrar o sonoro, o compositor, na verdade, visualiza não mais que as articulações de seus dedos e dos mecanismos de seu instrumento na produção das vibrações e da harmonia invisível, em complementaridade à inacessibilidade de toda dimensão perceptiva à percepção global de seus objetos, pois que aquilo que se ouve também nada mais é que um aspecto do inaudível. Ver a produção sonora, contudo, sacia certo anseio de concretude, subsidiando, pelas vias da ilusão, a esperança que preside todo desejo de conhecimento: arrancando do próprio corpo a abstração sonora que presidia a emissão vocal, o compositor acaba por transferir aquele invisível para o corpo instrumental que bem se vê. E, desta feita, dá-se mais um passo rumo a uma ainda maior abstração: aquela que, continuando tão abstrata quanto o som que se cantava, emana à distância pela vibração de um corpo que não o seu. A abstração do pensamento escritural do compositor apenas se distancia de seu corpo, e os sons, ainda que sempre invisíveis, acedem ao estatuto de objetos sonoros.

É irretorquível, desde então, a associação do gesto interpretativo à escuta dos sons, a tal ponto que, mesmo quando ausentes na situação de escuta em que se sabe de sua existência (como por exemplo na escuta de uma gravação de uma interpretação pianística), o gesto corpóreo é imaginado, reconstruído pela imaginação do ouvinte, para então ser associado aos sons que se escutam. Nesse contexto, defrontamo-nos com certa imaginação do invisível, e mesmo antes do advento da musique concrète, instaura-se uma acusmática pós-pitagórica, ainda que em sentido único, qual seja: a de uma situação acusmática - aquela que implica a escuta sem que se veja a proveniência física dos sons, mas cuja gestualidade responsável pelos sons que se escutam é, de algum modo, reconstituída no imaginário do ouvinte. Ainda não mais que isso.

Como quer que seja, pelo visto ou pelo não visto, emerge daí a noção de gesto musical, conceito este que preside sons de proveniência conhecida para, por complexos processos de contiguidade e similaridade, adentrarem mais tarde até mesmo o terreno dos sons 
inauditos, os quais, mesmo sem terem proveniência (re)conhecida, ou sem que sequer evoquem qualquer proveniência, reivindicam de todo modo seu caráter gestual, irrevogavelmente atado à certa motricidade, ao mesmo tempo em que o compositor se vê, mesmo que apenas em potência, cada vez mais alienado do som, objeto de sua objetivação.

\section{A prática musical dissociada do som}

Quando o compositor procurar então, aqui e acolá, se apossar de novo do gesto, resgatando a experiência vívida do compositor-instrumentista, o fará sobretudo pela incorporação de um gesto mudo, incapaz ele mesmo de emitir qualquer som, pois que investido, de certo modo, desse distanciamento então irreversível do pensamento compositivo em relação à produção dos sons.

E advém então um efetivo desligamento. Como num parto, o cordão umbilical que unia o compositor ao som como que se rompe de vez quando o compositor se apossa, pois, da batuta. Com ela, gesticula e controla a emissão dos sons, mas não os emite mais. Mune-se de um "instrumento mudo", dotado, porém, de enorme potência sonora. E isto em meio a um paradoxo: a regência só se estabelece justamente quando da multiplicação instrumental, e reger é como que, desesperadamente, tentar apossar-se de novo dos gestos que fazem emergir os sons. Mas são os músicos da orquestra, aprovisionados de seus respectivos instrumentos, outros corpos portanto, que os geram. Chegamos então em meados do século XIX, mais precisamente de seu fim e do início do século XX, quando então a figura do compositor-regente emerge com mais força do que a do compositor-instrumentista: Berlioz, Wagner, Mahler, Strauss, Schönberg, Webern, mais tarde Maderna, Boulez...

Oriundo de uma necessidade de coordenação coletiva, o ato da regência, exercido primordialmente pelo próprio compositor, metamorfoseia a frustração advinda da relativa perda de controle do som dissociado de seu corpo em instrumento de poder, resgatando este controle gestual à máxima potência, ao mesmo tempo que instituindo a autoridade por meio do gesto silencioso.

Claro está que a paulatina expurgação do som para fora do corpo do compositor, que aos poucos abre mão de seu contato direto com as vibrações sonoras, elucida uma prática musical cada vez mais dissociada com relação à própria produção sonora, ao menos à sua fisicalidade mais "concreta", mesmo que tal fenômeno, que atravessa os séculos até desaguar no advento da música eletroacústica, seja predominante, de forma alguma, porém, excludente com relação às atuações mais corporalizadas do fazer musical, as quais - do canto à performance instrumental - continuam a coabitar o espaço ativo do compositor. Tratase, pois, não de exclusões, mas antes de predominâncias, as quais revelam a inexorabilidade desta tendência geral e histórica: distanciar-se do som para fazer deste o objeto, sonoro, da mais pura abstração escritural.

\section{Os sons libertos de seus instrumentos}

Mas nenhuma história se estanca no ponto em que achamos que poderia estancar-se. A batuta muda e onipotente do compositor-regente está longe de constituir a última fase deste processo histórico, e a emergência das poéticas eletroacústicas - na forma da musique concrète a partir de 1948 e logo depois, a partir de 1949, da elektronische Musik - virá contribuir sobremaneira para o momentâneo ápice (que, como todo ponto culminante, pode ser 
transgredido e superado por algum lance tão imprevisível quanto o de um dado, até aqui sequer concebível) deste distanciamento corpóreo do compositor em relação ao som: deparando-se com o objeto sonoro desprovido de sua até então inexorável proveniência sonora, a escuta através de alto-falantes permite ao compositor que se desvencilhe das origens físicas do som, mesmo que - repetimo-lo - instaure-se aí uma busca de caráter gestual no âmago do sonoro. A situação acusmática verte-se, então, em estética acusmática, e o compositor passa a lidar com sons desprovidos dos traços físicos de sua gestação. Mais que isso, é a anulação mesma desta proveniência genética - como bem entrevira Schaeffer -, e só ela, que poderá propiciar ao compositor a escuta que lhe é então mais apropriada: aquela que se dá conta da fatura sonora, de sua gestualidade desprovida de gesto. Por mais que, pela vertente eletrônica, tenha-se preferido fazer uso dos instrumentos eletrônicos primordiais como geradores sonoros - em oposição à captação via microfone dos concretos -, mesmo aí o intuito era a mais imediata abstração sonora (e, nesse contexto histórico dos idos dos anos 1950, não por menos associada a princípios seriais, de alto potencial abstrato e com alto índice de racionalidade).

A situação que se instala é, entretanto, das mais paradoxais. Pois que tal percurso histórico rumo a esse distanciamento físico do compositor em relação ao som promoverá, em estúdio, um re-encontro substancial e novamente não mais intermediado por qualquer outro corpo humano, ou mesmo inumano: no laboratório eletroacústico, porém, o compositor toma contato direto com o material sonoro, livrando-se, senão em sua fase produtiva, ao menos em sua fase compositiva propriamente dita, de sua matéria, e tal desvinculação total, de tipo acusmático (ou seja, a partir do fato estético de que ouvimos os sons sem sequer ver ou mesmo (re)conhecer a sua proveniência física), nada mais faz que levar às últimas consequências aquela tendência já presente no decurso daquele processo de (salutar?) alienação do som em relação ao corpo do compositor, iniciado com a autonomia da música instrumental.

Primeiramente gerando o som dentro de si (o compositor-cantor), em seguida expelindo-o para fora de seu corpo e interagindo com outros corpos geradores de sons (o compositor-instrumentista), ao que depois se segue um desligamento do gesto em relação à própria produção do som (o compositor-regente), atinge-se por fim a era na qual o compositor concentra toda a sua energia produtiva nas etapas laboriosas do par decomposição/recomposição, debruçando-se sobre o material sonoro já então desvinculado de sua proveniência física, quando então nada mais interessa que - para parafrasearmos, por exemplo, um Varèse - a mais abstrata, ao mesmo tempo mais concreta, organização dos sons. A fisicalidade dos sons cede passo, então, à tautológica sonoridade dos sons. A “composição” configura-se no ato, isto sim, de uma re-composição, algo aqui potencializado ao máximo, mas justamente existente em potência desde os primórdios da escritura musical, amparada pela decomposição dos parâmetros sonoros tal como mediada pela escrita. E o substantivo composto que se incrusta na figura do compositor mais uma vez se transmuta, em que sua segunda faceta contesta e contrasta com a primeira: o compositor verte-se, aqui, em compositor-recompositor.

\section{Um triste episódio}

A revolução operada pelas poéticas eletroacústicas não as isenta de se submeterem, elas mesmas, a certa evolução. Ainda que o salto ao abstrato tenha se dado em plena fase do nascimento da música dita "concreta”, e que paradoxalmente, em sua vertente serial-eletrônica, a música eletroacústica tenha conhecido certa "instrumentalização" na geração sonora (através da utilização dos aparelhos eletrônicos como fontes sonoras primárias), e ainda que mesmo no seio da música concreta o microfone tenha exercido, com sua função essen- 
cialmente passiva, o papel de "instrumento", bien tempéré ${ }^{5}$, na captação dos objetos sonoros, é inegável o potencial abstrato que se estabelece com o apogeu da escritura quando das elaborações eletroacústicas, finalmente liberta de seu suporte notacional. Com o que denominei outrora de apoteose da escritura ${ }^{6}$ no contexto da composição eletroacústica, em que a processualidade tipicamente escritural é desvinculada do suporte da escrita e abre mão de toda mediação codificada típica da notação musical, aquele reencontro direto do compositor com o som em estúdio institui o paradoxo da mais alta abstração estar, de algum modo, associada a certa concretude do ato compositivo. Por vezes associada à atuação do pintor, a atividade do compositor do novo gênero eletroacústico, fazendo uso daquelas técnicas primordiais que viriam a ser designadas como analógicas, debruçava-se diretamente sobre a cor dos sons - seus timbres, aspecto constitutivo dos materiais -, em desenlace energético capaz de transformar o âmago mesmo dos espectros sonoros.

Mas a que evolução assistimos no decurso desses pouco mais de 60 anos do gênero eletroacústico? Não há fase na história da música em que não se ganhe por um lado e não se perca por outro. Para melhor elucidar o fato mais evidente deste repro-gresso, qual seja: o que vai da era analógica à digital, cabe aqui o relato de um acontecimento.

Fim de tarde, exaurido pelo prazeroso trabalho da composição, decidi dar-me o tempo de um café no centro da cidade do Embu das Artes, em cujas cercanias habito, em meio à floresta. Sentando-me à mesa e degustando calmamente um cappuccino, observo na mesa à minha frente uma família toda reunida, pai, mãe e casal de jovens filhos, ainda crianças. Ali permaneço por mais de 40 minutos. Mas o que deveria ser um momento de descanso começa a se transformar numa ebulição mental a contragosto, produto de certo inconformismo social advindo de minhas observações. Estranhei. Durante aqueles 40 minutos, não ouvi sequer um único vocábulo sair de qualquer uma daquelas quatro bocas à minha frente: a mãe, emburrada como que sem qualquer opção de algum fazer inteligente, pois que desprovida de qualquer aparelho que lhe desse certo alento; o pai, totalmente absorto com seu celular "inteligente"; o mesmo pode-se dizer do que ocorria com cada um de seus dois filhos, cada qual provisionado com seu próprio aparelho. Mas seria mentira afirmar que desconheci ao menos o timbre da voz do chefe da família. Entretanto, não foi aos seus que dirigiu suas poucas palavras. Ao final daquele longo tempo, o pai pede a conta ao garçom, efetua em seguida o pagamento e todos saem, sempre sem qualquer comunicação - verbal, ou mesmo por via de algum olhar (auris non audivit, nec oculus vidit) - entre os membros da sagrada família. Não bastasse a melancolia desta situação trágica de total incomunicabilidade, o pai, antes de deixar o recinto, lembra-se de se voltar para trás para certificar-se de que, uma vez pago por aquele consumo, tudo tivesse sido devidamente consumido, e deparando-se, de longe, com o copo ainda pela metade de um suco de frutas que o menino não desejara consumir ao todo, volta-se rapidamente, sozinho, à mesa e, mesmo sem qualquer necessidade que justificasse o desespero daquele ato, vira goela abaixo o que restara do suco do garoto. Afinal, o consumo teria que ser consumado! Em seguida, sai do recinto, agora um pouco menos triste que antes.

Este lamentável episódio, que me deixou em profundo estado de inconformismo, quase de revolta, serviu-me, de toda forma, como reviravolta, verdadeira epifania: ali a chave do mistério paradoxal da era moderna, mediada pelos smartphones e pelo assombroso volume de informações e de lixo da internet, era como que a mim desvendada. Numa crassa inversão das longitudes, a internet traz virtualmente a nosso lado distâncias colossais, continentais, ao mesmo tempo em que arremessa a anos-luz de distância aquilo de que nos sentiríamos mais achegados. Sonoriza na surdina laços distantes de relacionamento para emudecer e empalidecer as relações afetivas que mais nos são próximas. E mais uma vez 
o silêncio vem em socorro de uma pretensa autoridade, na ilusão de se apropriar do mundo. O que se situa muito longe, parece aproximar-se radicalmente; mas o que está tão perto, este fica, efetivamente, muito distante, numa consagração da hipocrisia que preside o que se achou por bem denominar de "redes sociais".

Longe de adotarmos aqui qualquer postura maniqueísta, é ululante que uma compreensão dialética das potencialidades digitais revela-se como a estratégia mais inteligente. Constatemo-lo: trazer para perto distâncias abismais é tão evidentemente legítimo e mesmo vantajoso quanto reconhecer a superioridade qualitativa da representação sonora digital em relação ao som analógico, defendido como um fetiche por espíritos saudosistas. Para tanto, contudo, não haveria de se pagar o alto preço da morte dos afetos, e mais, nem tampouco do amortecimento das pulsões pelas quais estes mesmos afetos nos movem, quer seja em relação a nossos amores, quer seja em relação a nossos sons, que amamos igualmente.

\section{O pensamento é analógico}

Reconhecer as limitações do analógico não equivale a desconhecer igualmente seus benefícios, e nesse contexto deparamo-nos com outro aspecto deveras problemático da era digital: o risco de uma constante e despropositada fragmentação do conhecimento, operacionalizada pelo recorrente impulso aos hyperlinks, em que mal se dá tempo para que se compreenda o objeto do conhecimento com o qual se defronta para, numa frenética sequência de clicks, remeter-se a cada segundo a qualquer outra faceta da informação, numa ilusória pretensão totalizante de conhecimento, mas que na verdade inviabiliza todo e qualquer aprofundamento do pensamento e da percepção. Em um certo sentido, o mouse converte-se em espécie de batuta, provida de semelhante sensação de ilusória onipotência. Uma batuta, porém, substancialmente piorada, pois enquanto a batuta, justamente por sua qualidade gestual, não abre mão da continuidade de seus gestos, o mouse verte-se, na quase ausência de motricidade e com seus intermitentes clicks, em contínuo e ininterrupto estopim de toda fragmentação.

Por mais que o pensamento possa se (re)instrumentalizar com os meios digitais, é evidente que sua essência é de índole analógica. Nenhum e-book, por mais prático que seja, poderá, por exemplo, substituir a ausência de luz artificial e a leitura de um livro impresso em um terraço banhado à luz do sol, leitura esta intermediada por advindas e necessárias interrupções (para um café, um cachimbo), num reabastecimento da energia pensante. Os afetos ocorrem em tempo real, pois são incapazes de se auto-regularem; já sua reflexão - o pensamento -, fundamentalmente em tempo diferido, estendido, alargado, sujeito a intercepções, interposições, reflexões, suspensões, interpolações de toda ordem. Neste caráter apenas aparentemente fragmentário consagra-se justamente seu essência contínua e estendida. As fragmentações dos hyperlinks, em contrapartida, são avessas a essa extensão temporal essencial e imprescindível para que o pensamento crítico possa amadurar.

E na essência deste cogente estiramento do tempo, de índole analógica e investido por seu caráter diferido, é que então lobrigamos o quão aquele reencontro primordial do compositor com o som em estúdio, ainda que não mais intermediado pela escrita nem pelos instrumentos habituais, resgatava certa corporeidade tão atuante em tempos remotos, mas que foi paulatinamente extirpada da prática da composição. Havia, naqueles recursos de forte apelo físico que residiam nas manipulações analógicas dos primórdios da música eletroacústica e que atravessariam diversas de suas fases até sua paulatina transição, em fins dos anos 1980, à nova fase digital, certa carga energética que habita - e só a ele - o gesto concreto, mesmo que visando à mais pura abstração em plena apoteose da processualidade escritural. 
Sob este prisma, o advento das poéticas eletroacústicas, lá em sua primeira fase analógica, acabou por instaurar uma apoteose não apenas da escritura em seu elevado potencial abstrato, mas também daquela almejada objetivação do som, historicamente tão perseguida pelo compositor, na medida em que, resgatando a gestualidade corpórea no controle dos sons, fazia-o em uma condição pela qual estes mesmos sons revelavam-se destituídos e sobretudo desvinculados de sua proveniência física. Assim fazendo-o, a era analógica levava ao apogeu também o gesto instrumental, pois que o controle e os processamentos dar-se-iam não mais na produção dos sons propriamente dita, mas antes em nível mais profundo e elevado (e com tal profundidade até então desconhecida por qualquer prática instrumental): o de suas constituições morfológicas e espectrais, na paleta de cores dos sons. Vista a questão sob tal ótica, tratou-se, aí, de se instituir - não de se inverter, porém - certa distância entre causa e efeito, pois é como se tanto objetos sonoros quanto gesto musical tivessem sido resguardados por um longo caminho que acabara por desvincular ambas estas facetas do fato sonoro e compositivo, instituindo entre ambas certo deslocamento, numa quebra da evidente causalidade. Resguardou-se, com isso, todo potencial gesticulatório para, entretanto, se exercer o controle mais fino sobre a materialidade sonora, em grau até ali jamais entrevisto por qualquer interpretação.

Mas justamente disso abre-se mão, ao menos em grande parte, com a digitalização dos recursos eletroacústicos. A quantos benefícios acedemos com a bem-vinda evolução dos meios digitais, sobre isso não será necessário aqui discorrermos de modo tão alongado. Mas se há evidência das vantagens de tais recursos, o mesmo pode-se dizer do quão perdemos com a era digital, se comparada com aquela força energética dos antigos procedimentos analógicos. Ganha-se em rapidez dos processos, em possibilidades de articulação simultânea e múltipla dos procedimentos, em conhecimento acerca das propriedades dos espectros, em qualidade na captação e reprodução do fato sonoro, bem como na qualidade e praticidade de sua armazenagem, sem falarmos da questão econômica, que democratiza o uso e mesmo abuso dos recursos eletrônicos, mas perde-se, em contrapartida, aquela aura que presidia a fisicalidade do gesto analógico, tão essencial e mesmo tipificadora dos aportes historicamente tão convincentes do advento do novo gênero em fins dos anos 1940 e início dos 1950, os quais promoveram a nova música eletroacústica ao peculiar estatuto de emancipação da composição face às limitações da música instrumental.

\section{Outro episódio: um final (?) feliz}

A era digital - constatamo-lo - consagra essa dessacralização do gesto corpóreo e de sua energia, entorpecendo a percepção com uma aparência de substancialidade. Tem-se acesso a tudo e corre-se o risco de não se conhecer nada, pois o tempo fracionado do acesso é incompatível com aquele outro, delongado e necessário ao conhecimento. E comete-se em estúdio o mesmo equívoco que hoje se faz recorrente com a problemática fragmentação do tempo real pelos hyperlinks. Mas em vista de suas incontestáveis vantagens, como conciliar seus recursos com aquela fisicalidade tão essencial ao pensamento (re)compositivo que impregnava o trabalho analógico?

Indubitavelmente um aspecto a se considerar é a especulação, conduzida a seu mais alto grau, sobre os próprios procedimentos digitais, como que resgatando ou procurando, de alguma forma, reconstruir métodos antes vivenciados pelas técnicas analógicas da composição eletroacústica. Em tal processo, não é rara a situação em que se (re)inventam novos procedimentos potencialmente tão "analógicos" quanto os de outrora, só que, agora, 
levados a cabo, e com ainda maior requinte, com recursos digitais. Tal solução, entretanto, torna-se realista e mesmo factível apenas quando operada por compositores que ainda tiveram o privilégio de vivenciarem esses mesmos procedimentos analógicos (e que souberam, obviamente, tirar proveito em sua devida época daqueles mesmos recursos), demonstrandose quase inviáveis - salvo esforço incomum, digno apenas de talento excepcional e de muita disciplina, aliás indispensáveis, ambos, ao grande compositor - a compositores das novíssimas gerações, os quais já emergem enquanto tais em plena era digital.

Mas na eleição primária dos elementos em que consiste, logo de partida, toda nova obra, quais sejam: em seus materiais constitutivos, seus sons, consiste a outra esperança, esta presente ontem, hoje e sempre, em se reconquistar a qualidade musical dos grandes marcos históricos do gênero. E é aqui que cabe o relato de mais um episódio.

Em novembro de 2013, participei como compositor convidado do Festival L'Espace du Son de Bruxelas, no qual, além de ter realizado, no dia 22, dois concertos acusmáticos, com a difusão eletroacústica de, entre outras peças por mim escolhidas, três de minhas obras em um portentoso arsenal de cerca de 80 alto-falantes, pude conviver com velhos amigos do meio eletroacústico internacional, que lá estiveram para prestigiar o evento. Destaco, nesse contexto, dois ilustres e idosos visitantes: Francis Dhomont e François Bayle. Estando no mesmo hotel deste segundo, não foram poucas as conversas entre nós, sempre aprofundadas, sobre diversos aspectos da contemporaneidade e da situação da música eletroacústica na atualidade em meio aos nossos cafés da manhã. E em um deles, queixando-me da letargia tão presente em grande parte dos meus alunos das gerações mais novas, como que entorpecidas por certa lassidão, por certo marasmo nos processos de composição em estúdio, cuja responsabilidade atribuo em grande parte à aparente comodidade ou facilidade das operações que se realizam com os meios digitais, Bayle manifesta-se a mim enfaticamente solidário e concordante, enaltecendo a relevância fundamental daquela fisicalidade perdida logo na fase inaugural de todo processo composicional em estúdio: la prise de son! Insistia no valor incomensurável em se continuar a buscar os próprios sons, em saber captá-los - ao invés de se contentar com a cômoda escolha dos materiais em meio aos infindáveis bancos de som que hoje qualquer sistema de armazenagem digital oferece ao (jovem) compositor, que deles pode se servir como que diante de farta mesa de inesgotáveis guloseimas a serem consumidas, entretanto, por um paladar nada aguçado, desmotivado, essencialmente inculto porque essencialmente não-especulativo. Saber captar os sons dos modos mais diversos, especular sobre a matéria bruta dos objetos, desvendar os meandros do sonoro: eis a defesa da fisicalidade promulgada por Bayle em meio a um simples café da manhã, de poucas escolhas.

Sábio conselho advindo de um mestre tão tarimbado! Lembrei-me então quando saí à caça dos sons da floresta em que vivo para a composição de Selva Illuminata (2006), ou da gravação, por diversos ângulos, de um ranger metálico de um velho forno para o início de Motus in fine velocior - in memoriam Stockhausen (2008), ou daquele portentoso som do elevador de piano em um teatro de São Paulo, o qual logo despertou meu interesse e que por isso tratei de captar de diversas maneiras, aproveitando-o depois ao início de Simultrans (2009-13). Ou ainda, em estúdio, como eu captara os diversos sons, em todas as suas nuances, de Pulsares (1998-2000) e Harmonia das Esferas (2000), quando então trouxe comigo ao estúdio de gravação tipos variados de esferas, distintas em tamanho e constituição, para, munido de diversos microfones, dispostos em diferentes pontos do estúdio mas também à mão, torpedear esfera contra esfera, raspá-las em superfícies diversas, envolvê-las com outros materiais, arremessá-las aos montes por sobre o assoalho como que simulando um big-bang na emergência de novas galáxias. Ali germinava em potencial todo o universo de uma 
de minhas mais ricas e complexas realizações nos territórios da música eletroacústica mista (Pulsares) ou acusmática (Harmonia das Esferas)...

A tomada de som, efetivamente, edifica aquele momento inaugural e sagrado da especulação - a mesma que deve persistir nas fases ulteriores da composição digital -, da intuição guiada pelas descobertas no contato com os objetos sonoros, do exercício da energia pensante transplantada ao trato dos materiais, ao manuseio da matéria e a certo resgate das afecções que nos atam aos objetos (sonoros) que perseguimos, formas de amor. É desse cultivo inaugural e afetivo que se nutrem as perlaborações instituídas na estruturação de uma obra eletroacústica significativa.

Desta feita - disto tenho convicção - a nova obra eletroacústica, ao mesmo tempo em que convalida a emergência e a história do gênero enquanto apogeu do pensamento abstrato da composição - e não abrindo mão de todas as aquisições que as novas tecnologias nos aportam! -, acaba também por legitimar aquele longo e prazeroso percurso secular, estendido como todo bom distanciamento do pensamento crítico, do som do corpo ao corpo do som, que perpassa os séculos da escritura, sem igualmente deixar de inverter outra distância profunda: traz, para bem perto de nós, aquela verve corporal e anímica dos sons vocais de tempos arcaicos, sem que, para tanto, façamos uso de nossos próprios corpos e abramos mão de nossas próprias almas.

\section{Curitiba (PR) / Itapecerica da Serra (SP), janeiro de 2014}

\section{Notas}

1 Este texto desenvolve uma das ideias presentes em um outro recente ensaio, intitulado "Suma teleológica da composição musical - por uma breve sociologia da recomposição”, escrito em 2013 e publicado em: Nascimento, Guilherme et alii. A Música dos Séculos 20 e 21. Série Diálogos com o Som. Belo Horizonte (Barbacena): EdUEMG, 2014, pp. 61-72.

2 “"My teacher Josquin [...] never gave a lecture on music or wrote a theoretical work, [...] but taught [his pupils] the rules in a few words, through practical application in the course of singing'. [...] With these words the German theorist and composer Adrianus Petit Coclico explained how Josquin taught music: first singing, then counterpoint, and finally composition".

3 “O olho não viu, nem os ouvidos ouviram”. Provérbio latino associado ao Apocalipse de Elias: "Sed sicut scriptum est: quod oculus non vidit nec auris audivit nec in cor hominis ascendit quae praeparavit Deus his qui diligunt illum" "“Mas como está escrito: aquilo que nenhum olho viu, nem nenhum ouvido ouviu, nem concebeu qualquer coração humano, eis o que Deus proveu àqueles que o amam”). A primeira sentença servira como título a um importante moteto de Orlando di Lasso (Oculus non vidit, de 1577), por mim analisado em meu primeiro livro: Menezes, Flo. Apoteose de Schoenberg: Tratado sobre as Entidades Harmônicas. 2. edição. São Paulo: Ateliê Editorial, 2002, p. 34-37.

4 "Lo que se muestra es un aspecto de lo invisible” (ANAXÁGORAS. Fragmentos. Buenos Aires: Aguilar, 1966, p. 66).

5 Assim Pierre Henry intitula sintomaticamente uma de suas obras acusmáticas do primeiro período: Le microphone bien tempéré (1950).

${ }^{6}$ MENEZES, Flo. Luciano Berio et la phonologie: Une approche jakobsonienne de son œuvre. Frankfurt am Main: Peter Lang, 1993, p. 58-66; em português: MENEZES, Flo (org.). Música eletroacústica: História e estéticas. São Paulo: Edusp, 1996 (2. edição: 2009), p. 33-37.

\footnotetext{
Flo Menezes (Florivaldo Menezes Filho) - Professor Titular da Unesp na área da Composição Eletroacústica. Possui graduação em Composição pela USP (1985), mestrado em Elektronische Komposition junto à MusikhochschuleKöln (1989), Alemanha, e doutorado em Arts et Sciences de la Musique - Université de Liège (1992), Bélgica. Tem experiência na área de Artes, com ênfase em Composição Musical, atuando principalmente nos seguintes temas: composição eletroacústica, composição musical contemporânea. Em 1994, fundou o Studio PANaroma da Unesp, do qual é Diretor Artístico. Em 2002, funda a orquestra de alto-falantes PUTS: PANaroma/Unesp - Teatro Sonoro.
} 